\title{
PENENTUAN HARGA POKOK BERAS DI KECAMATAN KOTAMOBAGU TIMUR KOTA KOTAMOBAGU
}

\author{
Juliana R. Mandei \\ Theodora Katiandagho \\ Charles R. Ngangi \\ Jilly N. Iskandar
}

\begin{abstract}
The research with the title "Determination of Floor Price of Rice in the Eastern District Kotamobagu, Kotamobagu City" was designed to determine the base price of rice in the district east of the city Kotamobagu Kotamobagu, and compare the prices of goods sold at market prices and government purchase price (HPP). This research was conducted from November to December 2010. Data obtained from primary and secondary data. Primary data obtained from direct interviews using a questionnaire to farmers, and primary data obtained from the relevant agencies. Determining the location of intentional (purposive sampling) where a small village and village Kobo Moyag chosen because it is the biggest rice producing region in the Eastern District Kotamobagu. The samples were farmers conducted by simple random sampling.Analysis of the data used is the method of Full Costing by summing the total component cost.

The results showed that the size of the average floor price in District of East Kotamobagu is Rp4961.56 per kilogram. The average floor price of rice in Sub Moyag higher than Kobo Small Village.
\end{abstract}

Keywords: Rice, Floor Price

\section{PENDAHULUAN}

\section{Latar Belakang}

Bagi masyarakat Indonesia komoditi beras bukan saja merupakan bahan pangan pokok, tetapi sudah merupakan komoditi sosial dan mempunyai peran dalam stabilitas politik, dan pertumbuhan ekonomi. Oleh karena itu, perubahan-perubahan yang terjadi pada beras akan begitu mudah mempengaruhi kehidupan sosial-ekonomi yang lain (Tjitrosemito, 1993).

Pemerintah melalui BULOG dan instansi membuat kebijakan harga dasar (floor price) untuk gabah kering giling (GKG) dan harga tertinggi (ceiling price) untuk beras yang pada hakekatnya merupakan intervensi terhadap mekanisme pasar. Pemerintah akan melakukan operasi pasar bila harga beras dipasaran dinilai jauh melampaui batas harga.

Berdasarkan Inpres No 7 tahun 2009 yang diundangkan akhir desember 2009 dan berlaku 1 Januari 2010 mematok HPP GKP, GKG, dan beras Rp. 2.640, Rp. 3.345, dan Rp. 5.060 per kilogram.
Harga pokok produksi adalah suatu aspek yang sangat penting dalam suatu usaha. Tanpa adanya perhitungan harga pokok produksi yang tepat dan benar, maka suatu usaha yang dijalankan tidak akan mengetahui dengan pasti keuntungan yang diperolehnya atau mungkin juga kerugian yang akan didapat.

Beras adalah salah satu komoditi andalan dan strategis bagi Kota Kotamobagu. Ini juga ditunjukan oleh banyaknya penduduk yang bermata pencaharian sebagai petani padi sawah. Kecamatan Kotamobagu Timur merupakan salah satu sentra produksi beras di Kota Kotamobagu. Dari sembilan kelurahan yang ada di Kecamatan Kotamobagu Timur, Kelurahan Kobo Kecil merupakan kelurahan yang memiliki luas lahan padi sawah terbesar di Kecamatan Kotamobagu timur, kemudian diikuti dengan Kelurahan Moyag.

\section{Perumusan Masalah}

Beberapa petani padi dikota Kotamobagu tidak mengolah usahataninya secara intensif karena pertimbangan harga yang ditetapkan terlalu rendah 
atau tidak dapat menutupi biaya-biaya yang dikeluarkan, oleh karena itu yang menjadi permasalahan adalah apakah harga beras yang ditetapkan pemerintah berada dibawah biaya produksi beras?

\section{Tujuan dan Manfaat Penelitian}

Penelitian ini bertujuan untuk mengetahui:

1. Harga pokok penjualan beras di kecamatan kotamobagu timur kota Kotamobagu.

2. Membandingkan harga pokok penjualan dengan harga pasar dan harga pembelian pemerintah (HPP).

Adapun manfaat dari penelitian ini adalah memberikan informasi dan pengetahuan bagi pembaca dan semua pihak yang membutuhkan.

\section{TINJAUAN PUASTAKA}

Harga adalah tingkat kemampuan suatu barang untuk diukar dengan barang lain (Kadariah, 1994). Menurut Lesmono (1998), harga pokok adalah nilai pengorbanan untuk memperoleh barang atau jasa yang diukur dengan nilai mata uang. Sedangkan menurut Kartasapoetra (1985) harga pokok merupakan jumlah biaya-biaya dari produk yang telah dikeluarkan.

Menurut halim (1990), terdapat 2 metode penentuan harga pokok yaitu:

1. Penentuan harga pokok produk yang konvensional atau penentuan harga pokok penuh (full costing), atau sering disebut dengan metode absortion costing atau conventional costing membebankan semua unsure biaya produksi baik yang bersifat tetap maupun variabel pada barang atau jasa.

2. Penentuan harga pokok variabel (variabel costing) merupakan metode penentuan harga pokok produk yang membebankan unsur biaya produksi yang yang bersifat variabel saja.

Untuk menghitung harga pokok persetiap satuan barang hasil produksi dilakukan dengan cara menjumlahkan semua biaya-biaya yang dikeluarkan dibagi dengan julmah produksi yang dihasilkan (Adikoesumah, 1973).

Menurut Lesmono (1988) harga pokok penjualan adalah jumlah semua biaya-biaya yang dikeluarkan sampai barang tersebut siap untuk dijual.

Menurut Sumodiingrat (1987), biaya adalah pengeluaran-pengeluaran yang dilakukan dalam usaha untuk menyelesaikan proses produksi. Biaya yang dikeluarkan oleh seorang petani dlam proses produksi serta membawanya menjadi suatu produk disebut biaya produksi ( Hernanto, 1989).

Menurut Djodjodiputro (1991) biaya adalah pengeluaran dalam bentuk proses produksi yang tidak dapat dihindarkan, sedangkan menurut Soekartiwi (1995), biaya usahatani adalah semua pengeluaran yang dipergunakan dalam suatu usahatani.

\section{METODOLOGI PENELITIAN}

\section{Metode Pengumpulan Data}

Penelitian ini menggunakan metode survey. Data yang dikumpulkan adalah data primer dan sekunder. Data primer diperoleh melalaui wawancara langsung dengan petani berdasarkan pertanyaan, sedangkan data sekunder diperoleh dari instansi-instansi yang terkait.

\section{Metode Pengambilan Sampel}

Penentuan lokasi dilakukan secara sengaja (purposive sampling) dimana Kelurahan Kobo kecil dan Kelurahan Moyag dipilih karena merupakan daerah penghasil padi terbesar di Kecamatan Kotamobagu Timur.sampel petani padi sawah sebanyak 15 orang dengan cara simple random sampling.

\section{Konsep Pengukuran Variabel}

Variabel yang akan diukur dalam penelitian ini, yaitu:

1. Luas lahan padi sawah (ha)

2. Biaya yang akan dikeluarkan mulai dari persemaian, pengolahan sawah, pemeli-haraan, panen, sampai pascapanen (Rp).

a. Biaya sarana produksi antara lain: Benih, Pupuk, Obat-obatan untuk pengendalian hama dan penyakit, dan Pupuk pelengkap

b. Biaya tenaga kerja terdiri dari: Persemaian, Pengolahan tanah, Pemeliharaan, yaitu pemupukkan dan pengendalian hama dan 
penyakit, Panen, dan Pascapanen yang terdiri dari jemur, rontok, dan giling.

c. Produksi (kg)

d. Pajak (Rp)

e. Sewa lahan (Rp)

f. Bunga modal (Rp)

g. Biaya penyusutan untuk peralatan.

Dalam penelitian ini penyusutan dihitung dengan menggunakan Metode Garis Lurus (Straight Line Method).

Jumlah penyusutan per tahun:

Dimana:

$$
I=\frac{B-S}{n}
$$

$$
\begin{aligned}
\mathrm{I} & =\text { Penyusutan } \\
\mathrm{B} & =\text { Harga beli } \\
\mathrm{S} & =\text { Nilai sisa } \\
\mathrm{n} & =\text { Umur ekonomis }
\end{aligned}
$$

\section{Analisis Data}

Data yang diperoleh akan disajikan dalam bentuk tabel dan dianalisis secara deskriptif. Untuk menghitung harga pokok penjualan beras per kg digunakan rumus:

Harga pokok penjualan per kg =

$$
\frac{\text { Jumlah biaya seluruhnyan }(R p)}{\text { Jumlah produksi yang dihasilkan }(K g)}
$$

\section{HASIL DAN PEMBAHASAN}

\section{Luas Lahan}

\section{Deskripsi Usahatani Padi Sawah}

Dalam melakukan usaha dibidang pertanian, lahan merupakan faktor produksi yang penting untuk menghasilkan suatu komoditi. Keadaan lahan serta luas dari lahan akan mempengaruhi produksi, biaya dan penggunaan tenaga kerja dari usahatani. Pada Tabel 1 disajikan data luas lahan padi sawah rata-rata menurut lokasi penelitian.

Tabel 1 menunjukkan rata-rata luas pemilikan lahan padi sawah pada desa Kobo Kecil sebesar 1,33 ha dan diikuti oleh desa Moyag sebesar 0,90 ha. Rata-rata luas lahan di kecamatan Kotamobagu Timur adalah sebesar 1,25 ha.
Tabel 1. Luas Pemilikan Lahan Padi Sawah Ratarata menurut Daerah Sampel

\begin{tabular}{|c|c|c|}
\hline Kelurahan & $\mathrm{N}$ & Luas Lahan (ha) \\
\hline Kobo kecil & 15 & 1,13 \\
\hline Moyag & 15 & 0,90 \\
\hline Rata-rata & 30 & 1,02 \\
\hline
\end{tabular}

Sumber: Data olahan, 2010

\section{Produksi}

Jumlah produksi padi sawah sangat bervariasi tergantung dari tingkat perawatannya. Bila tanaman tersebut dirawat dengan baik, dalam artian dibersihkan secara teratur, pemupukan yang tepat, dan pengendalian hama yang terpadu, maka produksi tanaman tersebut akan maksimal.

Tabel 2. Rata-rata Produksi Padi Sawah per Responden Menurut Daerah Sampel

\begin{tabular}{|c|c|c|}
\hline Kelurahan & $\mathrm{N}$ & Produksi $(\mathrm{kg})$ \\
\hline Kobo kecil & 15 & 1530.00 \\
\hline Moyag & 15 & 1214.55 \\
\hline Rata-rata & & 1372.27 \\
\hline
\end{tabular}

Sumber: Diolah Lampiran, 2010

Tabel 2 menunjukkan bahwa satu kali periode panen rata-rata produksi padi sawah pada luasan panen rata-rata 1,13 ha sebesar $1.530 \mathrm{~kg}$ pada Kelurahan Kobo Kecil atau sebesar 1.353,98 kg per ha, kemudian Desa Moyag sebesar 1.214,55 kg pada luasan panen rata-rata 0,90 ha atau sebesar 2.349,5 $\mathrm{kg}$ per ha. Ini berarti produksi yang dihasilkan petani di desa Kobo Kecil maupun desa Moyag relatif sama.

\section{Biaya Produksi Usahatani Padi Sawah Sarana Produksi}

Dari hasil penelitian ditemukan bahwa pupuk yang digunakan adalah Urea, TSP, KCL, Ponska, dan pupuk pelengkap yaitu Pelangi.

Tabel 3 menunjukkan rata-rata biaya sarana produksi pada usahatani padi sawah di kelurahan Kobo Kecil dan di Kelurahan Moyag. 
Tabel 3. Biaya Sarana Produksi Rata-rata Menurut Daerah Sampel

\begin{tabular}{|l|c|c|c|}
\hline \multicolumn{1}{|c|}{ Kelurahan } & $\begin{array}{c}\text { Pupuk } \\
\text { (Rp) }\end{array}$ & $\begin{array}{c}\text { Pestisida } \\
\text { (Rp) }\end{array}$ & $\begin{array}{c}\text { Herbisida } \\
\text { (Rp) }\end{array}$ \\
\hline Kobo Kecil & $402.823,52$ & $53.617,65$ & $55.748,66$ \\
\hline Moyag & $595.925,92$ & $41.481,48$ & $63.037,03$ \\
\hline Rata-rata & $488.295,04$ & $48.245,90$ & $58.486,76$ \\
\hline
\end{tabular}

Tabel 3 menunjukkan bahwa rata-rata biaya pupuk dan herbisida di Kelurahan Moyag lebih tinggi dibandingkan dengan Kobo Kecil, sebaliknya rata-rata biaya pestisida di Kelurahan Moyag lebih rendah Dario kelurahan Kobo Kecil.

\section{Biaya Tenaga Kerja}

Tenaga kerja merupakan faktor terpenting dalam menentukan lancar tidaknya aktivitas usahatani. Ditempat penelitian tenaga kerja digunakan mulai dari kegiatan persemaian, pengolahan lahan, panen, hingga pascapanen.

Tabel 4 menunjukkan rata-rata biaya tenaga kerja pada usahatani padi sawah di Kecamatan Kotamobagu Timur yaitu sebesar Rp3.399.725,00. Jika dibandingkan antara Kelurahan Kobo Kecil dan Kelurahan Moyag maka Kelurahan Moyag per hektarnya lebih besar dibandingkan dengan Kelurahan Kobo Kecil. Biaya yang paling besar dikeluarkan adalah biaya pasca panen (62,78\%) yang terdiri dari biaya jemur $(5,44 \%)$, biaya rontok
(25,58\%), dan biaya giling (31,76\%). Biaya rontok dan biaya giling dibayar secara natura yaitu biaya rontok satu banding dua puluh empat dan biaya giling satu banding sembilan dan bila di transfer ke harga beras maka akan di dapat biaya giling sebesar Rp1.079.823,00 (31,76\%), sedangkan biaya rontok Rp869.901,60 (25,58\%). Biaya tenaga kerja pengolahan lahan merupakan biaya kedua terbesar yaitu sebesar $\mathrm{Rp}$ 538.524,60 $(15,84 \%)$ dan yang paling kecil adalah biaya tenaga kerja persemaian yaitu Rp86.885,20 (2,25 $\%)$.

Tenaga kerja yang digunakan berasal dari dua sumber yaitu tenaga kerja dalam keluarga dan tenaga kerja luar keluarga, Tenaga kerja keluarga hanya bersifat membantu dengan tujuan untuk menghemat biaya, namum dalam penelitia ini tenaga kerja keluarga turut diperhitungkan sama halnya dengan tenaga kerja luar keluarga.

Sistem pemberian upah untuk tenaga kerja pengolahan lahan kedua desa bervariasi antara Rp40.000 dan Rp50.000 dengan syarat upah Rp40,000 biaya makan (rokok, makanan, dan minuan) ditanggung oleh pemilik sedangkan Rp50.000 biaya makan (rokok dan minuman) di tanggumg oleh petani. Untuk tenaga kerja jemur, sistem pemberian upah juga bervariasi sama seperti tenaga kerja pengolahan lahan yaitu Rp40.000 dan Rp50.000 dengan syarat biaya makan (rokok, makanan, minuman) ditanggung oleh petani.

Tabel 4. Rata-Rata Biaya Tenaga Kerja Per Hektar Pada Usahatani Padi Sawah Menrut Lokasi Penelitian

\begin{tabular}{|c|c|c|c|c|c|c|}
\hline \multirow{2}{*}{ Kegiatan } & \multicolumn{6}{|c|}{ Biaya Tenaga Kerja } \\
\hline & Kobo Kecil & $\%$ & Moyag & $\%$ & Total & $\%$ \\
\hline Persemaian & $168.750,00$ & 5,07 & $82.962,97$ & 2,23 & $86.885,20$ & 2,55 \\
\hline Pengolahan Lahan & $416.470,59$ & 12,52 & $692.222,20$ & 18,67 & $538.524,60$ & 15,84 \\
\hline Pemeliharaan & $198.529,41$ & 5,97 & $111.851,90$ & 3,01 & $108.524,60$ & 3,19 \\
\hline Panen & $410.000,00$ & 12,32 & $682.963,00$ & 18,42 & $530.819,70$ & 15,61 \\
\hline Pasca Panen & & & & & & \\
\hline Jemur & $165.882,35$ & 4,99 & $209.629,60$ & 5,65 & $185.245,90$ & 5,44 \\
\hline Rontok & $887.294,11$ & 26,67 & $848.000,00$ & 22,87 & $869.901,60$ & 25,58 \\
\hline Giling & $1.080 .000,00$ & 32,46 & $1.079 .600,00$ & 29,12 & $1.079 .823,00$ & 31,76 \\
\hline Total & $3.326 .926,47$ & 100,00 & $3.707 .230,00$ & 100,00 & $3.399 .725,00$ & 100,00 \\
\hline
\end{tabular}




\section{Biaya Angkutan}

Biaya angkutan dalam penelitian ini tidak dihitung, karena tempat gilingan sudah menyediakan angkutan apabila petani menggiling padinya di tempat gilingan tersebut.

\section{Pajak}

Besarnya pajak yang harus dibayar oleh petani ditentukan oleh luas lahan dan letak lahan. Di Kecamatan Kotamobagu Timur, pajak yang dikenakan per ha yaitu sebesar Rp100.000. Biaya pajak untuk kedua desa dapat dilihat pada Tabel 5.

Tabel 5. Rata-Rata Biaya Pajak Usahatani Padi Sawah Per hektar Menurut Lokasi penelitian

\begin{tabular}{|l|r|}
\hline \multicolumn{1}{|c|}{ Desa } & \multicolumn{1}{c|}{ Biaya Pajak (Rp) } \\
\hline Kobo Kecil & $113.333,3$ \\
\hline Moyag & $90.000,0$ \\
\hline Rata-Rata & $101.666,7$ \\
\hline
\end{tabular}

\section{Sewa Lahan}

Biaya sewa lahan adalah biaya biaya sewa atas lahan yang digunakan, Dari hasil penelitian semua repsonden mengelola lahannya sendiri,namun dari informasi yang di dapat sewa lahan yang berlaku di Kecamatan Kotamobagu Timur dibayar secara natura yaitu sebanyak 400 kg padi per hektar,

\section{Penyusutan}

Penyusutan merupakan salah satu unsur biaya yang perlu dimasukkan dalam perhitungan biaya, karena baik secara teknis maupun ekonomis nilai dari alat-alat produksi yang digunakan akan semakin berkurang.

Tabel 6. Rata-Rata Biaya Penyusutan Usahatani Padi Sawah per hektar Menurut Lokasi Penelitian

\begin{tabular}{|l|c|}
\hline \multicolumn{1}{|c|}{ Desa } & Biaya Penyusutan (Rp) \\
\hline Kobo Kecil & $35.980,39$ \\
\hline Moyag & $66.820,98$ \\
\hline Rata-Rata & $49.631,14$ \\
\hline
\end{tabular}

Tabel 6 menunjukkan rata-rata biaya penyusutan terbesar terdapat di Desa Moyag yaitu sebesar Rp66.820,98. Adapun alat-alat yang dihitung penyusutannya adalah cangkul, sekop, parang, tang semprot, bajak, mesin paras, dan traktor.

\section{Bunga Modal}

Dasar pemikiran bahwa uang yang diinvestasikan dalam usahatani untuk jangka waktu tertentu tidak dapat bergerak bebas atau tidak dapat dignakan untuk keperluan lain, Oleh karena itu, penanaman ini menimbulkan biaya atas kesedian melepaskan kesempatan menggunakan uang tersebut untuk sementara waktu. Biaya bunga modalbergerak/variabel yang besarnya mengikuti tingkat bunga bank.

Tabel 7. Rata-Rata Biaya Bunga Modal Usahatani Padi Swah per hektar Menurut Lokasi Penelitian

\begin{tabular}{|l|c|}
\hline \multicolumn{1}{|c|}{ Desa } & $\begin{array}{c}\text { Biaya Bunga Modal } \\
\text { (Rp) }\end{array}$ \\
\hline Kobo Kecil & $213.418,2$ \\
\hline Moyag & $258.771,7$ \\
\hline Rata-Rata & $233.492,7$ \\
\hline
\end{tabular}

Tabel 7 menunjukkan rata-rata bunga modal terkecil yaitu Desa Kobo Kecil, Biaya bunga modal ini mengikuti bunga deposito yang berlaku untuk satu tahun sebesar $6 \%$.

\section{Harga Pokok Penjualan Beras}

Dalam penelitian ini harga pokok penjualan beras dihitung berdasarkan:

1. Harga pokok Penjualan beras yang terdiri dari biaya produksi eksplisit dan implisit.

2. Harga pokok penjualan beras tanpa biaya implisit.

Tabel 8 menunjukkan besarnya biaya rata-rata per ha yang dikeluarkan pada usahatani padi sawah di kecamatan Kotamobagu Timur yaitu sebsar Rp6.697.021,70. Biaya tersebut terdiri dari biaya eksplisit Rp3.304.313,88 dan implisit Rp3.392.707,84. 
Tabel 8. Biaya Produksi Eksplisit dan Implisit Rata-rata per hektar pada Usahatani Padi Sawah Menurut Lokasi Penelitian

\begin{tabular}{|l|r|r|r|}
\hline \multirow{2}{*}{ Jenis Biaya } & \multicolumn{2}{|c|}{ Besarnya biaya } & \multirow{2}{*}{ Rata-Rata } \\
\cline { 2 - 3 } & $\begin{array}{c}\text { Kobo Kecil } \\
\text { (Rp) }\end{array}$ & \multicolumn{1}{c|}{ Moyag (Rp) } & \\
\hline Persemaian & $479.103,08$ & $296.888,89$ & $354.557,30$ \\
Pengolahan & & & \\
Lahan & $416.70,71$ & $692.222,22$ & $538.524,41$ \\
Pemeliharaan & $512.189,99$ & $700.444,44$ & $595.027,54$ \\
Panen & $410.000,10$ & $682.963,00$ & $530.819,50$ \\
Pasca panen & $2.377 .294,82$ & $2.137 .229,63$ & $2.134 .970,00$ \\
Pajak & $80.000,02$ & $3.213 .259,00$ & $99.999,97$ \\
Sewa Lahan & $2.160 .000,63$ & $2.160 .000,00$ & $2.159 .999,29$ \\
Bunga & & & \\
Modal & $213.418,03$ & $258.771,55$ & $233.492,58$ \\
Penyusutan & $35.980,40$ & $66.820,99$ & $49.631,13$ \\
\hline Total & $6.684 .457,80$ & $10.208 .599,70$ & $6.697 .021,70$ \\
\hline
\end{tabular}

Dari Tabel 9 menunjukkan bahwa rata-rata harga pokok beras di Kelurahan Moyag lebih tinggi dibandingkan dengan Kelurahan Kobo Kecil. Tingginya biaya disebaban karena tingginya biaya tenaga kerja yang diakibatkan oleh penggunaan tenaga kerja yang berlebihan di Kelurahan Moyag. Rata-rata penggunaan tenaga kerja pengolahan tanah per hektar di Kelurahan Moyag adalah 11,63 HOK lebih tinggi dibandingkan dengan Kelurahan Kobo Kecil yang hanya sebesar $6 \mathrm{HOK}$.

Tabel 9. Harga Pokok Penjualan Beras Berdasarkan Biaya Eksplisit dan Implisit

\begin{tabular}{|l|r|c|c|}
\hline Desa & Biaya (Rp) & $\begin{array}{l}\text { Produksi } \\
\text { (Rp) }\end{array}$ & $\begin{array}{c}\text { Harga } \\
\text { pokok } \\
\text { penjualan } \\
\text { (Rp/kg) }\end{array}$ \\
\hline $\begin{array}{l}\text { Kobo } \\
\text { Kecil }\end{array}$ & $6.684 .457,80$ & $1.350,00$ & $4.951,45$ \\
\hline Moyag & $10.208 .599,70$ & $1.349,50$ & $7.564,72$ \\
\hline $\begin{array}{l}\text { Rata- } \\
\text { Rata }\end{array}$ & $6.697 .021,70$ & $1.349,78$ & $4.961,56$ \\
\hline
\end{tabular}

Jika dibandingkan dengan harga yang ditetapkan pemerintah Rp5.060 maka, harga pokok beras di Kelurahan Kobo masih lebih rendah, sedangkan harga pokok beras di Kelurahan Moyag lebih tinggi dari harga yang di tetapkan pemerintah. Namun, secara keseluruhan rata-rata harga pokok beras di kecamatan Kotamobagu Timur lebih rendah dari harga yang ditetapkan pemerintah.

Harga pokok beras dengan hanya berdasarkan biaya eksplisit dapat dilihat pada Tabel 10.

Tabel 10. Harga Pokok Penjualan Beras Berdasarkan Biaya Eksplisit

\begin{tabular}{|l|c|c|c|}
\hline \multicolumn{1}{|c|}{ Desa } & $\begin{array}{c}\text { Biaya } \\
\text { (Rp) }\end{array}$ & $\begin{array}{c}\text { Produksi } \\
\text { (Rp) }\end{array}$ & $\begin{array}{c}\text { Harga } \\
\text { pokok } \\
\text { penjualan } \\
\text { (Rp/kg) }\end{array}$ \\
\hline $\begin{array}{l}\text { Kobo } \\
\text { Kecil }\end{array}$ & $3.556 .971,63$ & $1.350,00$ & $2.634,79$ \\
\hline Moyag & $4.312 .859,25$ & $1.349,50$ & $3.195,89$ \\
\hline $\begin{array}{l}\text { Rata- } \\
\text { Rata }\end{array}$ & $3.891 .542,98$ & $1.349,78$ & $2.883,09$ \\
\hline
\end{tabular}

Tabel 10 menunjukkan jika harga implisit tidak diperhitugkan baik di Kelurahan Kobo Kecil maupun Kelurahan Moyag rata-rata harga pokok penjualan beras jauh dibandingkan dari yang di tetapkan pemerintah yaitu Rp5.060.

\section{KESIMPULAN}

1. Besarnya rata-rata harga pokok di Kecamatan Kotamobagu Timur adalah Rp4961,56 per kilogram. Jika dilihat menurut Kelurahan sampel, rata-rata harga pokok beras di Kelurahan Moyag lebih tinggi dibandingkan dengan Kelurahan Kobo Kecil. Tingginya harga pokok beras di Kelurahan Moyag disebabkan oleh tingginya penggunaan tenaga kerja.

2. Rata-rata harga pokok beras di Kecamatan Kotamobagu Timur lebih rendah dari harga yang ditetapkan pemerintah. Namun jika dilihat menurut kelurahan sampel, harga pokok beras di Kelurahan Kobo Kecil lebih rendah daripada yang di tetapkan pemerintah, sedangkan harga pokok beras di Kelurahan Moyag lebih tinggi dari harga yang ditetapkan oleh pemerintah. 


\section{DAFTAR PUSTAKA}

AAK, Tanaman Padi, Aksi Agraris kanisius, Yayasan Kanisius Yogyakarta, 1973.

Adikoesoemah, Soemita, R, 1982. Biaya dan Harga Pokok, Bandung: Tarsito.

Daljono, 2004. Akuntansi Biaya Penentuan Harga Pokok dan Pengendalian.

Wordpress.com/ tag/skripsi jurnalskripsi.com.

Kotler, P, 2004. Manajemen Pemasaran, PT, IDEKS, Jakarta.

LM Samryn, 2001. Akuntansi Manajerial Suatu Pengantar, Jakarta: Cetakan Pertama, PT, Raja Grafindo Persada.

Mas’ud Mahfoedz,1993. Akuntansi Manajemen, Yogyakarta sBuku Satu, Edisi IV, Cetakan Ketiga, BPFE -Universitas Gajah Mada.

Mulyadi, 2000. Akuntansi Biaya, Yogyakarta: Aditya Media.
Mursid, M, 1997. Manajemen Pemasaran, Pusat Antar Universitas - Studi Ekonomi Universitas Indonesia, Bumi Aksara, Jakarta.

Stoner, James,, 1996. Manajemen (Edisi Bahasa Indonesia), PT, Prenhallindo, Jakarta.

Sukirno, Sadono, 2000. Pengantar Teori Mikroekonomi, Jakarta : PT Raja Grafindo Persada.

Sumarni, Murti,, John Soeprihanto, 2005. Pengantar Bisnis (Dasar-Dasar Ekonomi Perusahaan), Liberty Yogyakarta, Yogyakarta.

Supriyono, RA, 1999. Akuntansi Biaya, Yogyakarta: BPFE.

Suratman, 2001. Studi Kelayakan Proyek, J \& J Learning, Yogyakarta.

Umar, Husein,, 2007. Studi Kelayakan Bisnis, PT, Gramedia Pustaka Utama, Jakarta. 